\title{
THE RELATION BETWEEN UNIT WEIGHT AND GEOCHEMICAL AND MINERALOGICAL COMPOSITIONS IN THE FINE FRACTION OF TILL
}

\author{
JARI MÄKINEN
}

\begin{abstract}
MÄKINEN, JARI, 1992. The relation between unit weight and geochemical and mineralogical compositions in the fine fraction of till. Bull. Geol. Soc. Finland 64, Part 1, 59-74.

A routine method for measuring the unit weight (UW) of the fine fraction of till was developed. The material was crammed into a $1.5 \mathrm{ml}$ glass tube with a laboratory shaker for $75 \mathrm{sec}$. The upper half of the material was then poured away, and the volume and weight of the remainder were measured. The correlation coefficient of duplicate measurements is 0.995 .

Concentrations of $\mathrm{Co}, \mathrm{Cu}, \mathrm{Fe}, \mathrm{Mn}, \mathrm{Ni}, \mathrm{Pb}$ and $\mathrm{Zn}$ were determined by $\mathrm{AAS}$ from the fine fraction of till. Abundances of chlorite, hornblende, K-feldpspar, mica (di- and triochtaedral) and quartz (CL, HB, KF, MI, QU) were determined by the $\mathrm{X}$-ray diffraction (XRD) method. The grain-size distribution of the fine fraction was determined by X-ray sedigraph.

Examination of the material revealed close interrelationships between the geochemical, mineralogical and physical properties of the fine fraction of till. UW increases as the abundances of $\mathrm{HB}, \mathrm{KF}, \mathrm{PL}$ and QU increase proportional to $\mathrm{CL}$ and MI. This is reflected in a decrease in concentrations of $\mathrm{Co}, \mathrm{Cu}, \mathrm{Fe}, \mathrm{Mn}, \mathrm{Ni}$, $\mathrm{Pb}$ and $\mathrm{Zn}$, and in the abundance of clay-sized material. The correlation between UW and mineralogical composition is related to the grain-size distribution of the fine fraction and/or different mineral shapes of phyllosilicates and quartz and feldspars.

UW in the fine fraction of the weathered bedrock depends on the specific gravity of minerals, and not on the mineral shape as in till. The quartiles of UW in the weathered bedrock data are $1.43,1.52$ and in the till data 1.50, 1.70.

The increase in the proportion of $\mathrm{HB}, \mathrm{KF}, \mathrm{PL}$ and QU compared to those of $\mathrm{CL}$ and $\mathrm{MI}$ in till depends mainly on the grade of maturity. Hence the bulk of the total variation in the geochemical composition is explained by glacial factors, and only a minor part by bedrock. Close to the till/bedrock interface, however, the bedrock effect to the total compositional variation of till is more important. Because the till maturity is reflected in the mineralogical composition, the grade of maturity can be estimated with the aid of UW. The parameter also enables glacial and bedrock factors to be distinguished from geochemical till data.
\end{abstract}

Key words: till, fines, unit weight, geochemistry, mineralogy, bedrock, statistical analysis, Quaternary, Ruukki, Finland.

Jari Mäkinen: Geological Survey of Finland, Pb Box 1237, SF 70701 Kuopio, Finland.

\section{Introduction}

Geochemical till data have dual characteristics since geochemical anomaly patterns conform both with bedrock and with glacial geology (Salminen 1980, Peuraniemi 1982, Dilabio 1990, Lestinen et al. 1991). Thus the subject is a controversial one, and different methods of distin- 
guishing glacial and bedrock factors in till data have been developed (Gustavsson \& Kontio 1990, Mäkinen 1991).

Dealing with the problem solely with statistical or geochemical methods may result in excessive complexity or in a meaningless broadening of the element spectrum. However focusing the study on a few physical parameters may yield an interesting viewpoint to till geochemistry. The importance of physical properties of till comes out as concordance between the multielement concentration level and the clay-sized fraction in the fine fraction of till (Lintinen 1989, Stewart \& Broster 1990, Räisänen et al. 1992).

The incentive to examine the relationships between unit weight (UW) and the geochemical, mineralogical and other physical properties of the fine fraction came from the finding that physical properties are reflected in geochemical composition. The method was selected with a view to ease measurements, thus enabling UW to be determined with routine methods.

Mineralogical determinations are of paramount importance in establishing causalities between the physico-chemical properties of the till fine fraction. In this respect many studies focus on the clay mineralogy of the fine fraction (see Räisänen et al. 1992), but besides phyllosilicates a major part of the mineral species in the fine fraction composes of quartz and feldspars. The enrichment of quartz relative to less resistant minerals has therefore a profound influence to the mineralogical and geochemical composition of the fine fraction as the transport distance of till increases (Dreimanis \& Wagners 1971, Perttunen 1977, Haldorsen 1983). The compositional trend of till to a mineralogically stable state is a consequence of glacial comminution and outwashing and the trend can be expressed as increase of the maturity. According to Haldorsen

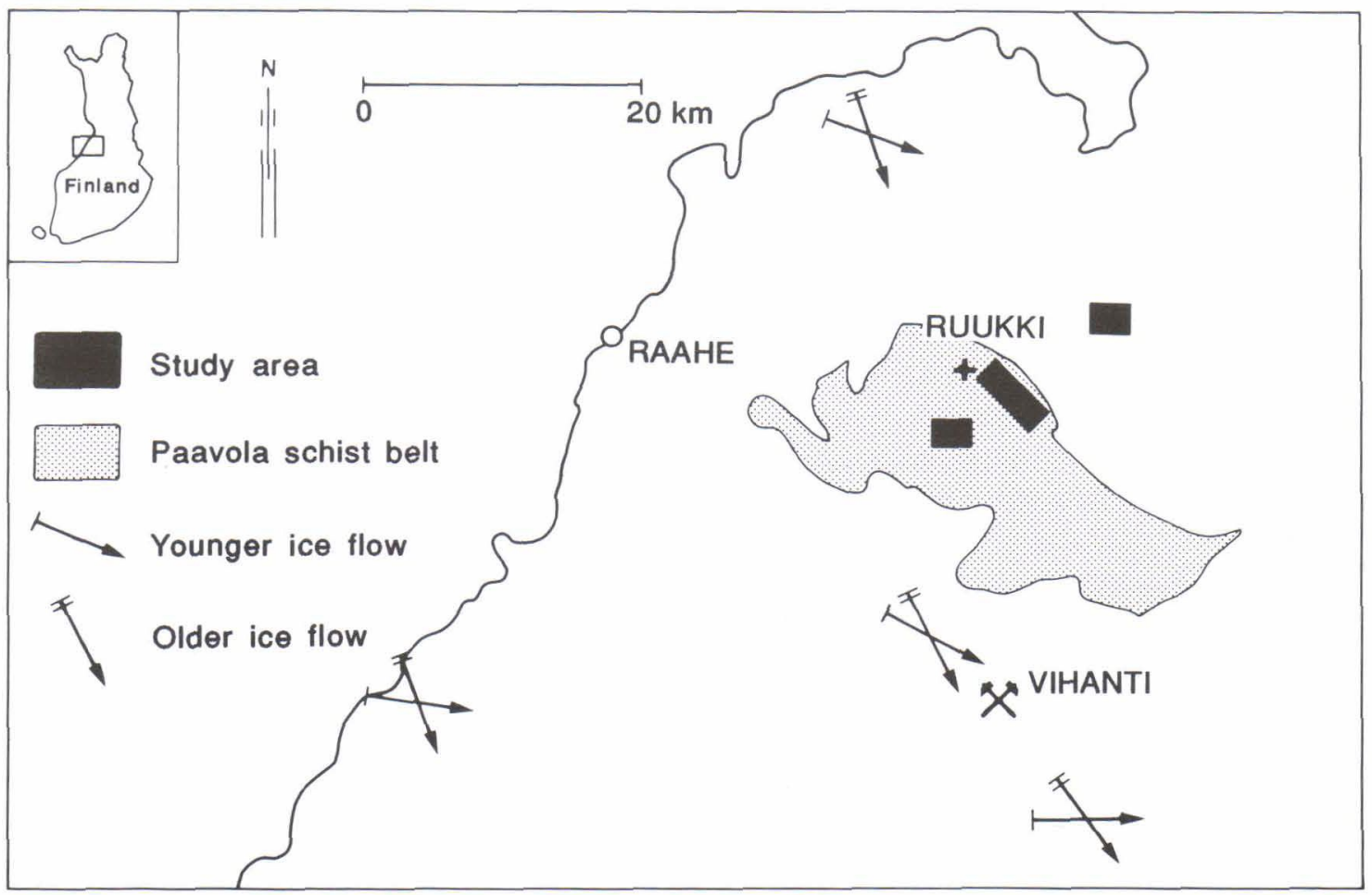

Fig. 1. The study area in the Paavola schist belt (Nykänen 1959). Ice flow directions after Hirvas et al. (1988). 
(op cit.) comminution increases the proportion of phyllosilicates with respect of quartz but effect of outwashing is reverse. In fact the compositional trend/maturity is dependent on the resistance of minerals and on the susceptibility to outwashing.

The aim of the study is to elucidate relationship of the geochemical and mineralogical composition and UW of the fine fraction of till to the maturity. Maturity is reflected in the study material as an increase in abundance of quartz and feldspars in relation to phyllosilicates. The main target of the study is to test if the multielement concentration level of the till fine fraction is reduced and UW increased as the maturity of till increases. Determination of UW should enable us to appraise degree of maturity and to distinguish glacial and bedrock factors from geochemical till data.

\section{Study material and geological background}

The study material was collected from Ruuk$\mathrm{ki}$, a municipality in Ostrobothnia, lying about $30 \mathrm{~km}$ north of Vihanti mine (Fig. 1). The bedrock of the study area in the Paavola schist belt consists mainly of Svecofennian sedimentogenic and volcanogenic schists with graphite- and sulphide-bearing horizons. Remnants of Jotnian sedimentary rock occur sporadically. The main constituent of the infracrustal rocks is a mediumgrained granitoid (Nykänen 1959).

Studies of till stratigraphy in Ostrobothnia have revealed two till beds of different age (Nenonen et al. 1990), the younger one transported from the west and the older one from northeast (Fig. 1). Organic material in till has been observed in the Vihanti area (Kauranne 1979, Nenonen 1985). Till geochemistry in the Vihanti area has been studied by Kauranne (op cit.). Only weak correlation between the chemical composition of the upper till and the bedrock was observed. The same is concluded by Björklund et al. (1976).
The study area is flat, and about $70 \%$ of it is wetland. The bedrock is almost totally covered by a layer of approximately 10-m-thick Quaternary sediments.

The structure of the glacial deposits consists generally of three units; the top consists of sand or gravel, the middle of loose, sandy, silty or stony till, and the bottom of compact, sandy till or material containing local weathered bedrock (Fig. 11a). At Tuohimaa and Koiramaa interglacial organic material occurs abundantly within the lowermost parts of the strata.

Altogether 445 samples from till and weathered bedrock were collected from 145 sampling stations (see Fig. 11a) using hydraulic and Cobra percussion drills. Some of the samples (288) were set aside for chemical analysis.

The target of sampling was the till/bedrock interface. Some of the samples were taken from the upper portions of the till at intervals of 0.5$1 \mathrm{~m}$. Duplicate samples were also taken. The sampling was partially directed by ground penetrating radar (GPR) (Fig. 12).

\section{Analytical methods}

The till and weathered bedrock samples were dried at $80^{\circ} \mathrm{C}$ and sieved into three fractions: $20-2 \mathrm{~mm}$ (L fraction), $0.5-0.06 \mathrm{~mm}$ (K fraction) and $<0.06 \mathrm{~mm}$ (fine fraction).

For flame-AAS analysis, a laboratory sample weighing $0.5 \mathrm{~g}$ was digested in aqua regia at $90^{\circ} \mathrm{C}$ and the concentrations of $\mathrm{Co}, \mathrm{Cu}, \mathrm{Fe}, \mathrm{Mn}, \mathrm{Ni}$, $\mathrm{Pb}$ and $\mathrm{Zn}$ were determined. The concentrations of $\mathrm{Co}, \mathrm{Cu}, \mathrm{Mn}, \mathrm{Ni}, \mathrm{Pb}$ and $\mathrm{Zn}$ were given in ppm and those of $\mathrm{Fe}$ in percentages.

Element concentrations are partly dependent on the amount of quartz and feldspars as a diluting components.

The mineralogical composition of the fine fraction was determined by XRD (x-ray diffraction method) for 169 till and bedrock samples, from which the percentages of quartz, K-feldspar, plagioclase, hornblende, mica (di- and trioc- 
taedral) and chlorite (QU, KF, PL, HB, MI, CL) were then calculated. For details see Räisänen et al. (1992).

The number of mineral species determined by $\mathrm{XRD}$ is limited and quality of measurments is semiquantitative. E.g. sulphides are ignored which may in some cases affect the results.

The grain-size distribution of the fine fraction of 63 till samples was determined using a Sedigraph 500ET. The chemical, mineralogical and physical determinations of the fine fraction were made in the laboratories of the Geological Survey of Finland.

\section{Unit weight measurement of the fine fraction of till.}

For measurement of the UW there exists geotechnical standards and one of them is the natural state of the sample (Soveri \& Kauranne 1972). In this study, however, UW is measured from the fractionated and crammed till samples and therefore the concept UW in this context differs from that used to describe natural soils. In fact UW is determined by specific gravity of the fine fraction and compressibility, which depends on the grain-size distribution and shape of minerals.

As no standard method was available, the first task was to develop a procedure for measuring the UW of the fine fraction of till (cf. Nieminen 1985). Good quality measurements apparently depended on efficient cramming: the tighter the material was crammed, the better was the correlation between geochemical variables and also the precision of the measurements. Efficient cramming increases also the values of UW.

The most satisfactory results were obtained with a $1.5 \mathrm{ml}$ glass tube, $3 \mathrm{~mm}$ in diameter and $260 \mathrm{~mm}$ long. The capacity of the rammer was inversely proportional to the size of the tube, which meant that cramming was more effective in the small $(1.5 \mathrm{ml})$ than in the big $(10 \mathrm{ml})$ tube. The lowermost part of the material became more tightly compressed than the upper part, and thus

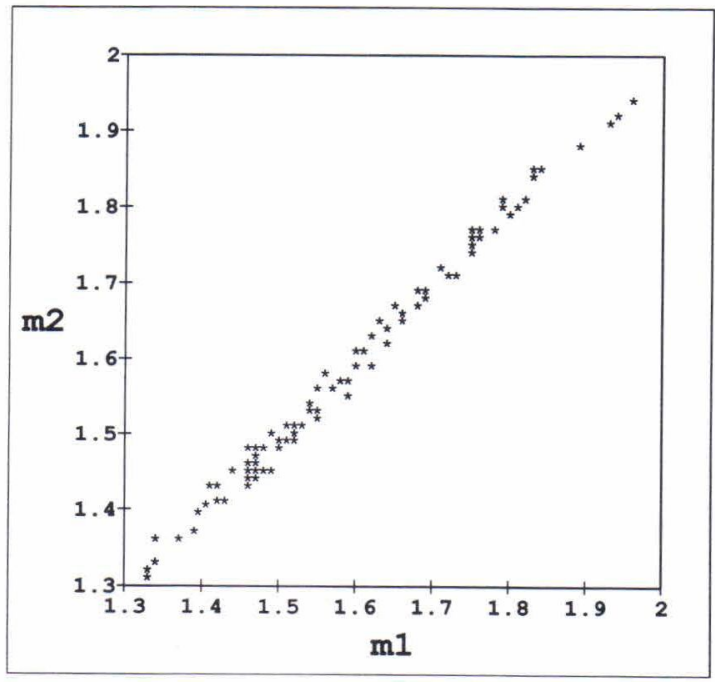

Fig. 2. Bivariate plot of duplicate UW measurements. Product moment correlation coefficient of the measurements was 0.995 .

the upper half of the material was poured away to improve the result.

A Vortex laboratory shaker was turned into a rammer by preventing the rotation of the tube with a plastic block.

The UW of the fine fraction of till and weathered bedrock was measured as follows: the fine fraction was crammed into a $1.5-\mathrm{ml}$ glass tube $75 \mathrm{sec}$. The uppermost half of the material in the tube was then poured away, and the volume and weight of the remainder were measured using the volumetric scale of the glass tube.

The precision of the method was checked by replicate measurements. As shown by Fig. 2 and the correlation coefficient $(r=.995)$, the conformity of the measurements was good.

\section{Statistical methods}

The aim of the statistical data processing was to establish the correlations between UW and the geochemical and mineralogical variables. The results were examined to test the validity of the hypothesis that the multielement concentration 
level decreases as the maturity of the till increases. Unit weight played a key role in the argumentation. Non-statistical evaluation of the hypothesis will be discussed on the basis of selected sampling stations.

Scatter plots were examined with the Spearman's rank correlation coefficients. The use of the rank correlation for geochemical data is recommended since nonparametric methods are less sensitive to anomalous values than the parametric method (Nikkarinen et al. 1991).

Multidimensional scaling and factor analysis were used to unravel complicated variable relationships from rank correlation matrices. Linear regression was also used to examine the dependences of variables (Norusis 1990).

Multidimensional scaling is an ordination method, which expresses a multivariate dataset as a two-dimensional scatter plot. This method is based on the Euclidean distances of vectors instead of angles between vectors as in the case in factor analysis (Schiffman et al. 1981). Measuring unit level by multidimensional scaling is ordinal in this case and thus the method is more robust than factor analysis.

The data processing was divided into four parts, and the data $(n=288)$ into subsets according to that division. First the pooled till data were processed $(n=179)$. Then the duplicate samples and the samples from different depths at the same sampling station were compared with each other $(n=71)$. Next the data of weathered bedrock $(n=79)$ were examined and after that correlations between UW and clay content (CC) and the other variables were briefly examined $(n=66)$.

\section{Results and interpretations}

\section{The pooled till data}

Processing the pooled till data $(n=179)$ revealed negative correlations between UW and elements as shown in Figs. 3a-3g. The correlations were highest for $\mathrm{Fe}, \mathrm{Mn}, \mathrm{Co}$ and $\mathrm{Ni}$ and lowest for $\mathrm{Cu}, \mathrm{Pb}$ and $\mathrm{Zn}$ (Table 1). A general multielement feature is the decrease in the scatter of concentrations with the incresase in UW. The scatter is lowest when UW exceeds 1.7, but increases in »lighter» material.

The relatively high scatter at high UW values is characteristics for $\mathrm{Mn}$, and it does not affect the concentrations of other elements.

The dependence of Fe on UW was examined with linear regression analysis (Fig. 4). The linear correlation between variables was made with e-base logarithm translation. The results indicate that $78 \%$ of the Fe variation can be explained by UW.

The relation between UW and geochemical

Table 1. Correlation matrix resulting from Spearman's rank correlation coefficients of the pooled till data. Bold letter means statistically siginificant correlation with UW.

\begin{tabular}{|c|c|c|c|c|c|c|c|c|c|c|c|c|c|}
\hline $\mathrm{Cu}$ & .54 & & & & & & & & & & & & \\
\hline $\mathrm{Mn}$ & .77 & .34 & & & & & & & & & & & \\
\hline $\mathrm{Ni}$ & .84 & .72 & .72 & & & & & & & & & & \\
\hline $\mathrm{Pb}$ & .64 & .83 & .41 & .71 & & & & & & & & & \\
\hline $\mathrm{Zn}$ & .62 & .79 & .46 & .73 & .77 & & & & & & & & \\
\hline $\mathrm{Fe}$ & .87 & .58 & .89 & .85 & .67 & .68 & & & & & & & \\
\hline UW & -.73 & -.46 & -.75 & -.69 & -.59 & -.54 & -.81 & & & & & & \\
\hline $\mathrm{CL}$ & .35 & .33 & .43 & .32 & .32 & .29 & .43 & -.38 & & & & & \\
\hline MI & .56 & .32 & .44 & .58 & .37 & .40 & .52 & -.44 & .16 & & & & \\
\hline $\mathrm{HB}$ & -.18 & -.18 & -.01 & -.20 & -.22 & -.16 & -.13 & .00 & .00 & -.36 & & & \\
\hline QU & -.17 & -.09 & -.15 & -.15 & -.10 & -.16 & -.17 & .11 & -.08 & -.47 & .26 & & \\
\hline PL & -.39 & -.19 & -.41 & -.44 & -.28 & -.29 & -.45 & .41 & -.27 & -.70 & .25 & .05 & \\
\hline \multirow[t]{2}{*}{ KF } & -.53 & -.28 & -.39 & -.47 & -.30 & -.29 & -.44 & .34 & -.17 & -.60 & .16 & .18 & .15 \\
\hline & $\mathrm{Co}$ & $\mathrm{Cu}$ & $\mathrm{Mn}$ & $\mathrm{Ni}$ & $\mathrm{Pb}$ & $\mathrm{Zn}$ & $\mathrm{Fe}$ & UW & $\mathrm{CL}$ & MI & HB & QU & PL \\
\hline
\end{tabular}



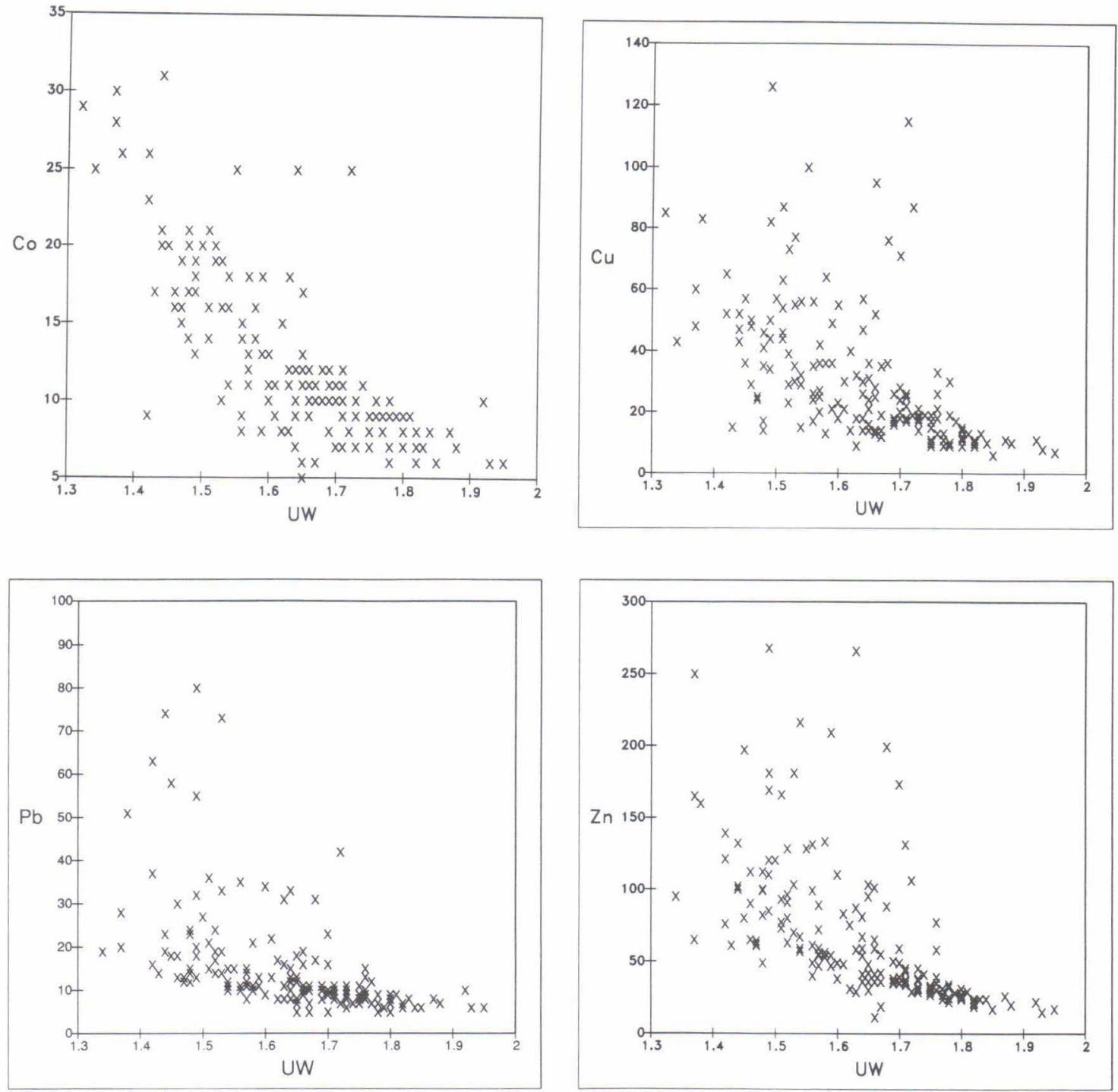

Figs. $3 \mathrm{a}-3 \mathrm{~g}$. Bivariate plots of $\mathrm{Co}, \mathrm{Cu}, \mathrm{Mn}, \mathrm{Ni}, \mathrm{Pb}, \mathrm{Zn}(\mathrm{ppm})$, and $\mathrm{Fe}(\%)$ against $\mathrm{UW}$ in the fine fraction of till.

composition can be linked to the mineralogy of the fine fraction. The relationships are shown in Fig. 5, where HB, KF, PL, QU plot diametrically opposite CL and MI. The configuration of the variables reveals that of $\mathrm{Co}, \mathrm{Cu}, \mathrm{Fe}, \mathrm{Ni}, \mathrm{Pb}$ and $\mathrm{Zn}$ are associated with $\mathrm{CL}$ and MI. Variation in UW can be deduced from the abundances of $\mathrm{HB}+\mathrm{KF}+\mathrm{PL}+\mathrm{QU}$ to $\mathrm{CL}+\mathrm{MI}$. The variable configuration in Fig. 5 was obtained by unfold- ing the rank correlation matrix in Table 1 with multidimensional scaling.

The correlation between the UW and the mineralogical composition is statistical significant (Table 1). It seems that the shape of minerals in the till material affect more to UW than specific gravities $\left(\mathrm{D}_{\mathrm{KF}}=2.6, \quad \mathrm{D}_{\mathrm{QU}}=2.65, \mathrm{D}_{\mathrm{PL}}=2.7\right.$, $\mathrm{D}_{\mathrm{CL}}=2.9, \mathrm{D}_{\text {biotite }}=3.0, \mathrm{D}_{\text {muscovite }}=2.85$ ). Powder constituting of mica plates and clay minerals are 

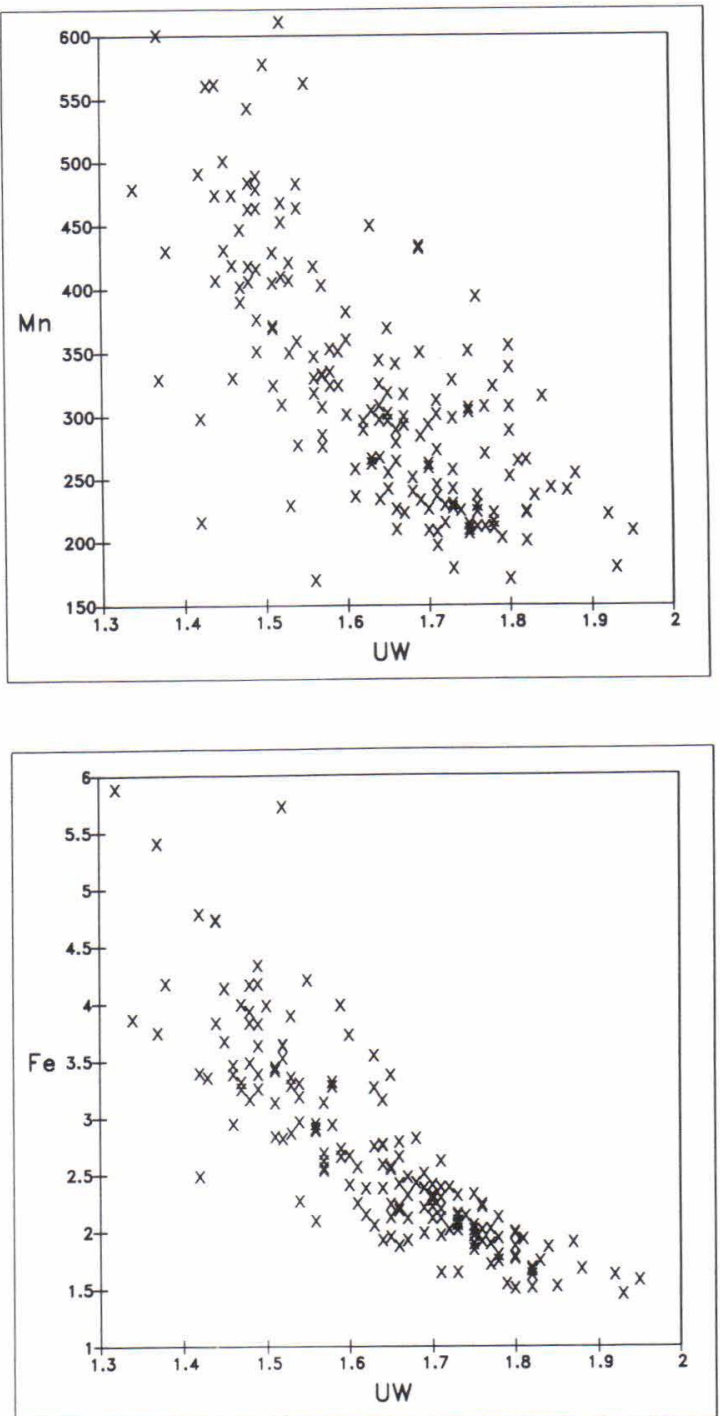

apparently less compressible than that of equidimensional feldspar and quartz grains. Efficiency of packing seem to depend also on the grain-size distribution, but strict examination of the causalities is beyond the present study.

Factor analysis was also performed on the correlation matrix, and the factor 1 support the inferences made on the relationships between mineralogy, UW and geochemical composition

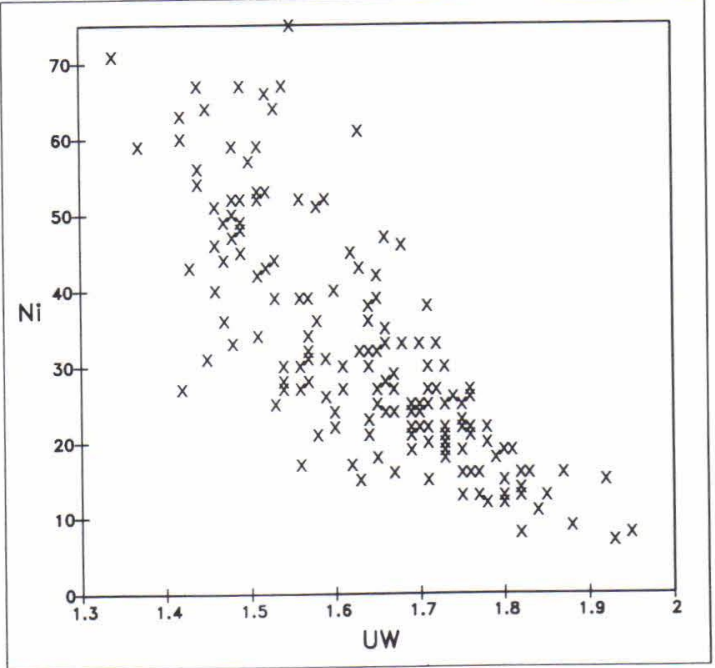

(Table 2). On the basis of the factor 2, there exists some independence between mineralogical and geochemical composition in till, because MI, HB and QU bear highest loadings.

The first stage of data processing revealed thorough trend in the characteristics of the fine fraction, there being strong covariations between the geochemical, mineralogical and physical parameters. On the basis of matrix configuration (Fig. 5) only mineralogical aspects cause the observed variation in the maturity of till. This is supported also by processing the duplicate and overlaying till data and the bedrock data. It was further deduced that the grade of maturity can be expressed with UW.

\section{Duplicate samples and samples from different depths}

The pooled data deriving mainly from areally scattered samples include the areal variation in glacial condition and bedrock composition (Figs. $3 a-3 g)$. Duplicate samples $(n=10)$ were compared (=local variation) to emphasize the glacial process of one stage. Pairs of samples from different levels of a till bed at the same sampling station were also compared, i.e. the ratio of the element content in the upper sample to the ele- 


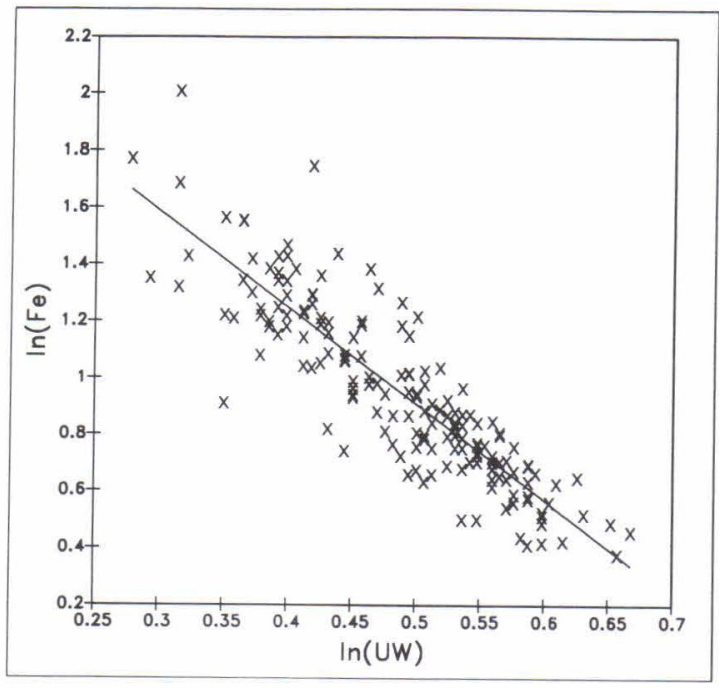

Fig. 4. Dependence of Fe on UW according to linear regression analysis. $78 \%$ of the Fe variation can be explained by UW.



Fig. 5. Configuration of the correlation matrix in Table 1 expressed in two dimensions with multidimensional scaling. The figure is based on pooled till data. Chlorite $=\mathrm{CL}$, hornblende $=\mathrm{HB}, \mathrm{K}$-feldspar $=\mathrm{KF}$, mica $=\mathrm{MI}$, plagioclase $=\mathrm{PL}$, quartz $=\mathrm{QU}$.

ment content in the lower sample was established (see Fig. 11a). The vertical distance between the samples was mostly $0.5-1 \mathrm{~m}$. The majority of the pairs represent the same till unit, but at some

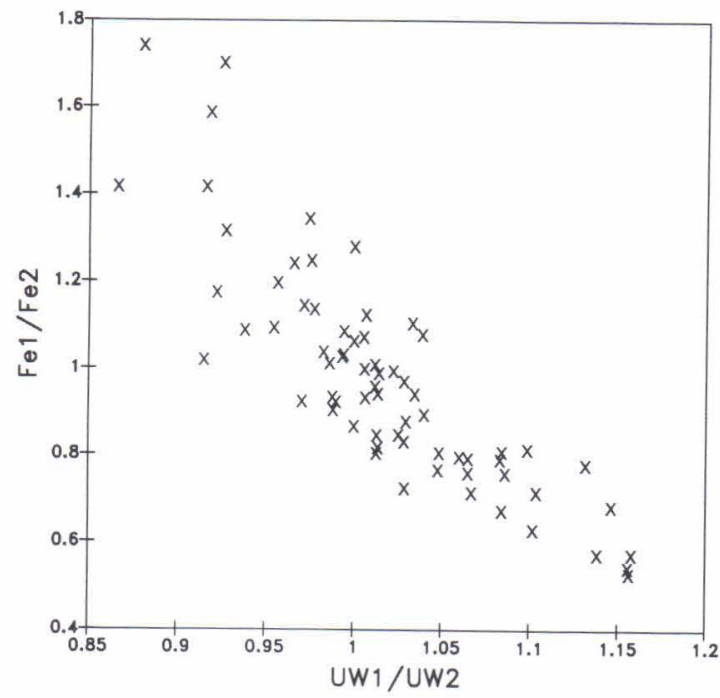

Fig. 6. Relative values of Fe and UW in pairs of duplicate samples and samples from different horizons.

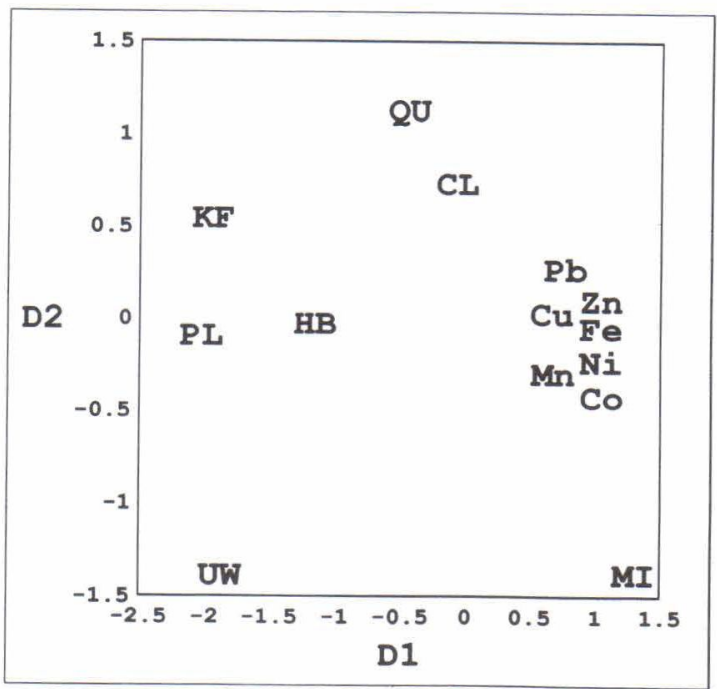

Fig. 7. Configuration of the rank correlation matrix calculated from the bedrock data in Table 3. Dimensions (D1 and D2) are not comparable to those of Fig. 5.

sites they differed in age and were eliminated from further examination (see Figs. 11a and 12).

As the comparison of duplicate samples and samples from different depths gave similar and 
Table 2. Result of the factor analysis from the matrix in Table 1 .

\begin{tabular}{lrrr}
\hline & F1 & F2 & F3 \\
\hline $\mathrm{Co}$ & .89 & .02 & -.12 \\
$\mathrm{Cu}$ & .72 & .27 & .52 \\
$\mathrm{Mn}$ & .79 & .09 & -.45 \\
$\mathrm{Ni}$ & .91 & .07 & .05 \\
$\mathrm{~Pb}$ & .78 & .23 & .43 \\
$\mathrm{Zn}$ & .78 & .20 & .38 \\
$\mathrm{Fe}$ & .92 & .12 & -.18 \\
$\mathrm{UW}$ & -.80 & -.18 & .27 \\
$\mathrm{CL}$ & .46 & .21 & -.22 \\
$\mathrm{MI}$ & .68 & -.63 & -.08 \\
$\mathrm{HB}$ & -.24 & .58 & -.44 \\
$\mathrm{QU}$ & -.25 & .58 & -.13 \\
$\mathrm{PL}$ & -.53 & .35 & .25 \\
$\mathrm{KF}$ & -.54 & .30 & .10 \\
\hline
\end{tabular}

statistically significant results, the materials were combined and the data were reprocessed $(n=71)$. The results indicate that the relation between UW and concentration is similar within a till bed (local variation) and on the scale of the entire data set (local + areal variation). Thus the relation between the element concentrations and UW is accounted for the maturity of till. Only relative values of UW and the relative variation in the concentration of $\mathrm{Fe}$ between 0.5 and 1.75 are given (Fig. 6).
Table 4. Result of the factor analysis from the matrix in Table 3.

\begin{tabular}{lrrrr}
\hline & F1 & F2 & \multicolumn{1}{c}{ F3 } & F4 \\
\hline $\mathrm{Co}$ & .80 & .38 & -.12 & -.02 \\
$\mathrm{Cu}$ & .36 & .77 & -.03 & -.09 \\
$\mathrm{Mn}$ & .79 & .20 & .01 & -.01 \\
$\mathrm{Ni}$ & .79 & .46 & -.10 & .05 \\
$\mathrm{~Pb}$ & .22 & .76 & -.13 & .22 \\
$\mathrm{Zn}$ & .57 & .55 & -.00 & .17 \\
$\mathrm{Fe}$ & .78 & .36 & -.00 & .16 \\
$\mathrm{UW}$ & -.25 & -.38 & .23 & -.54 \\
$\mathrm{CL}$ & .14 & .65 & .43 & -.12 \\
$\mathrm{MI}$ & .34 & -.02 & -.85 & -.24 \\
$\mathrm{HB}$ & -.09 & .18 & .64 & -.22 \\
$\mathrm{QU}$ & -.04 & -.06 & .05 & .89 \\
$\mathrm{PL}$ & .11 & -.40 & .77 & -.00 \\
$\mathrm{KF}$ & -.73 & .31 & .26 & .04 \\
\hline
\end{tabular}

\section{The data of weathered bedrock}

The rank correlation coefficients between variables were also calculated from the data of weath-

Table 5. Correlation of $\mathrm{UW}$ and $\mathrm{CC}$ between $\mathrm{Co}, \mathrm{Cu}, \mathrm{Mn}$, $\mathrm{Ni}, \mathrm{Zn}, \mathrm{Pb}, \mathrm{Fe}, \mathrm{CL}$ and $\mathrm{MI}$.

\begin{tabular}{|c|c|c|c|c|c|c|c|c|c|}
\hline UW & .73 & .49 & .79 & .72 & .64 & .59 & .86 & .42 & .39 \\
\hline $\mathrm{CC}$ & .51 & .22 & .75 & .49 & .38 & .32 & .67 & .43 & .19 \\
\hline & & & & & $\mathrm{Pb}$ & 21 & re & $\mathrm{CL}$ & $M$ \\
\hline
\end{tabular}

Table 3. Correlation matrix resulting from Spearman's rank correlation coefficients of bedrock data. For explanations see Table 1.

\begin{tabular}{|c|c|c|c|c|c|c|c|c|c|c|c|c|c|}
\hline $\mathrm{Cu}$ & .59 & & & & & & & & & & & & \\
\hline $\mathrm{Mn}$ & .64 & .32 & & & & & & & & & & & \\
\hline $\mathrm{Ni}$ & .92 & .72 & .64 & & & & & & & & & & \\
\hline $\mathrm{Pb}$ & .42 & .74 & .29 & .54 & & & & & & & & & \\
\hline $\mathrm{Zn}$ & .56 & .63 & .53 & .70 & .56 & & & & & & & & \\
\hline $\mathrm{Fe}$ & .78 & .44 & .73 & .72 & .43 & .68 & & & & & & & \\
\hline UW & -.36 & -.24 & -.29 & -.37 & -.44 & -.38 & -.45 & & & & & & \\
\hline $\mathrm{CL}$ & .26 & .43 & .35 & .28 & .34 & .38 & .31 & -.19 & & & & & \\
\hline MI & .34 & .11 & .29 & .29 & .13 & .13 & .21 & -.18 & -.25 & & & & \\
\hline НВ & -.06 & .00 & -.02 & -.07 & .01 & -.07 & -.03 & .17 & .34 & -.39 & & & \\
\hline $\mathrm{QU}$ & -.06 & -.12 & -.05 & .02 & .13 & .06 & -.04 & -.23 & -.10 & -.23 & -.06 & & \\
\hline PL & -.21 & -.17 & -.09 & -.18 & -.26 & -.15 & -.14 & .25 & .01 & -.64 & .24 & -.04 & \\
\hline \multirow[t]{2}{*}{$\mathrm{KF}$} & -.41 & -.12 & -.39 & -.44 & -.09 & -.23 & -.33 & .11 & .13 & -.55 & .20 & .02 & -.06 \\
\hline & $\mathrm{Co}$ & $\mathrm{Cu}$ & $\mathrm{Mn}$ & $\mathrm{Ni}$ & $\mathrm{Pb}$ & $\mathrm{Zn}$ & $\mathrm{Fe}$ & UW & $\mathrm{CL}$ & MI & $\mathrm{HB}$ & QU & PL \\
\hline
\end{tabular}




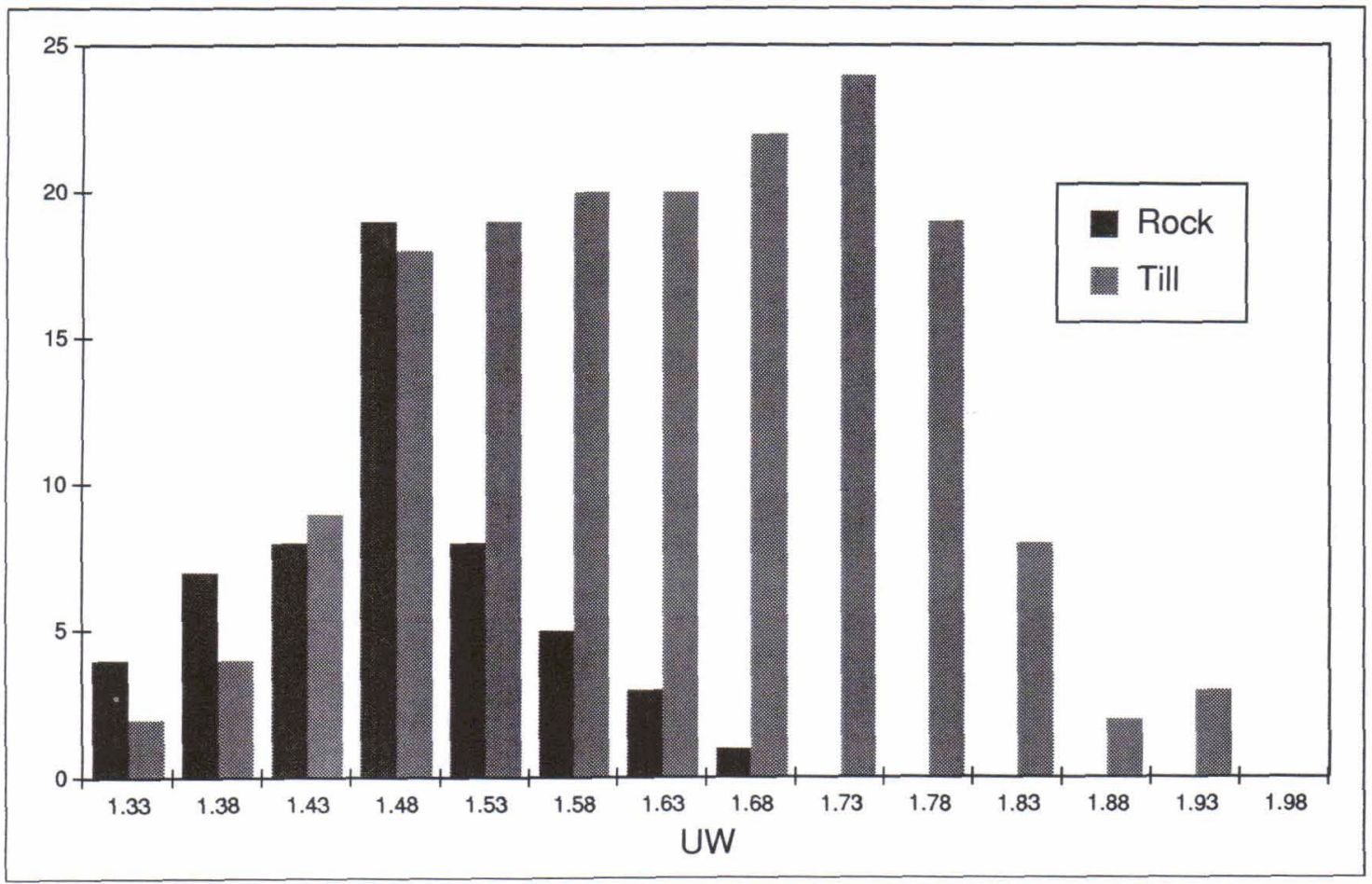

Fig. 8. Frequency distribution of UW of bedrock and till samples.

ered bedrock $(n=79)$, (Table 3). Multidimensional scaling and factor analysis were applied to the matrix (Fig. 7, Table 4). The relationships between mineralogy and geochemical composition and UW are more complicated as those of till (Table 2, Fig. 5).

According to factor analysis UW of the fine fraction of weathered bedrock is related mostly on the specific gravity of minerals, because UW and QU have highest loadings in the factor 4 i.e. shape of minerals affect to a lesser amount to UW in weathered bedrock than in till. Opposite relationships of QU and UW can be seen also in Fig. 6.

In the other factors loadings of UW are rather low. The first factor reflect the variation of compositional scale between red granitoids and supracrustal schists. According to the second factor $\mathrm{Cu}, \mathrm{Pb}$ and $\mathrm{Zn}$ are associated with chlorite (sulphides are ignored in this context). The third factor indicates independence of the mineralogical and geochemical composition, which is possibly a consequence of the limited scale of mineral species.

The variation in UW values is less marked in the fine fraction of weathered bedrock than in till. Quartiles of UW in the till data are 1.50, 1.70 and in the weathered bedrock data $1.43,1.52$. It suggest the dominant role of glacial maturity for UW in till (Fig. 8).

\section{Clay-content and UW of the fine fraction}

The abundance of clay-sized material $(<0.002$ $\mathrm{mm})(\mathrm{CC})$ in the fine fraction was also determined and was found to correlate well with UW (Fig. 9). The absolute values of the correlation 


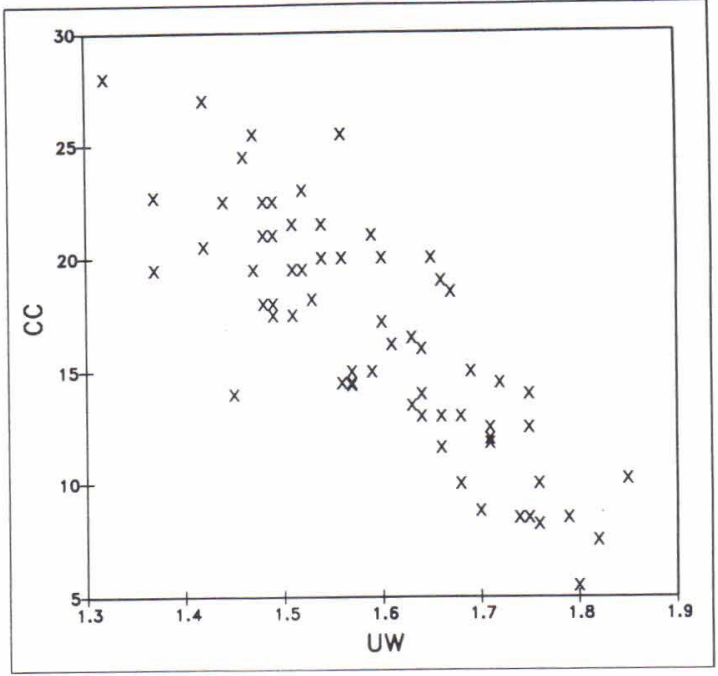

Fig. 9. Clay content (u) of the fine fraction vs. UW.

coefficients between CC and other variables are, however, lower than those for UW (Table 5). For positive correlations, opposite numbers of UW were calculated, and the configuration of the matrix was presented with multidimensional scaling. The difference in relationships between UW, CC and the geochemical variables is shown in Fig. 10 , where UW plots among elements, but CC lies farther away from the element cluster. It is irrelevant whether the better multielement correlation with UW than with CC is natural or is due to a difference in precision; what matters is that it proves the applicability of UW to till geochemistry.

\section{Discussion and conclusions}

The data processing was formulated to establish the dependence of the physical, mineralogical and chemical properties of the fine fraction of till. Different statistical approaches indicated that the multielement concentration level decreases as UW increases owing to an increase in

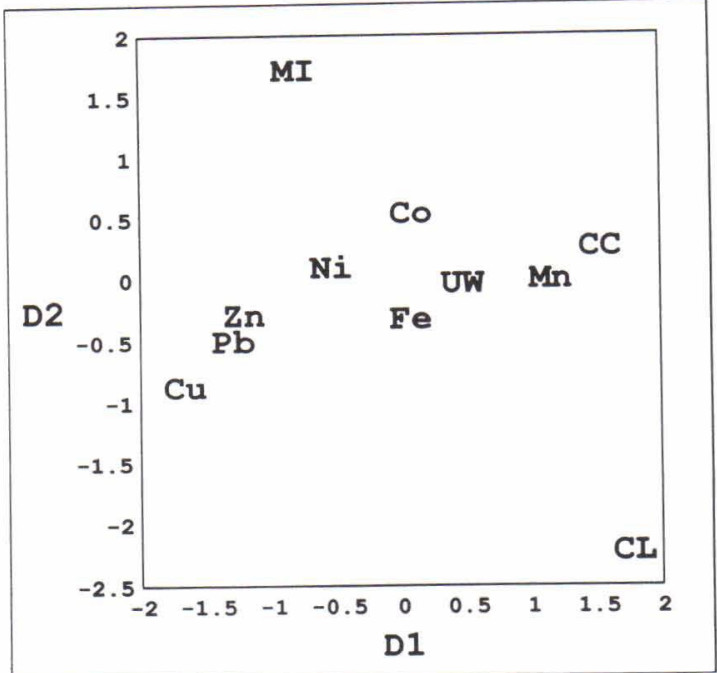

Fig. 10. The configuration of the rank correlation matrix in Table 5. Note that opposite numbers of UW were calculated for the correlation matrix.

the abundances of feldspars and quartz relative to those of mica and chlorite (Figs. $3 a-3 g, 5$ ). The main cause of this trend is increase of maturity linked with glacial processes. Bedrock affects to the trend to a lesser amount.

The physical and geochemical properties of the fine fraction of weathered bedrock are more complicated than those of till (Tables 2 and 4). UW in the weathered bedrock data depends on the specific gravity of minerals, whereas UW in till is related to the proportion of phyllosilicates with respect to that of QU and PL. The distribution of UW is more limited in the weathered bedrock data as in the till data, indicating the effect of glacial processes to UW. The study of duplicate samples and samples from different depths led to the same conclusion (Fig. 6). Maturity of till generally increases toward upper level of till units, complicating the situation as later will be discussed.

Fundamental control of maturity is the difference in the resistance of minerals and susceptibility to outwashing, and this seems explicitly to result in the enrichment of feldspars and quartz 


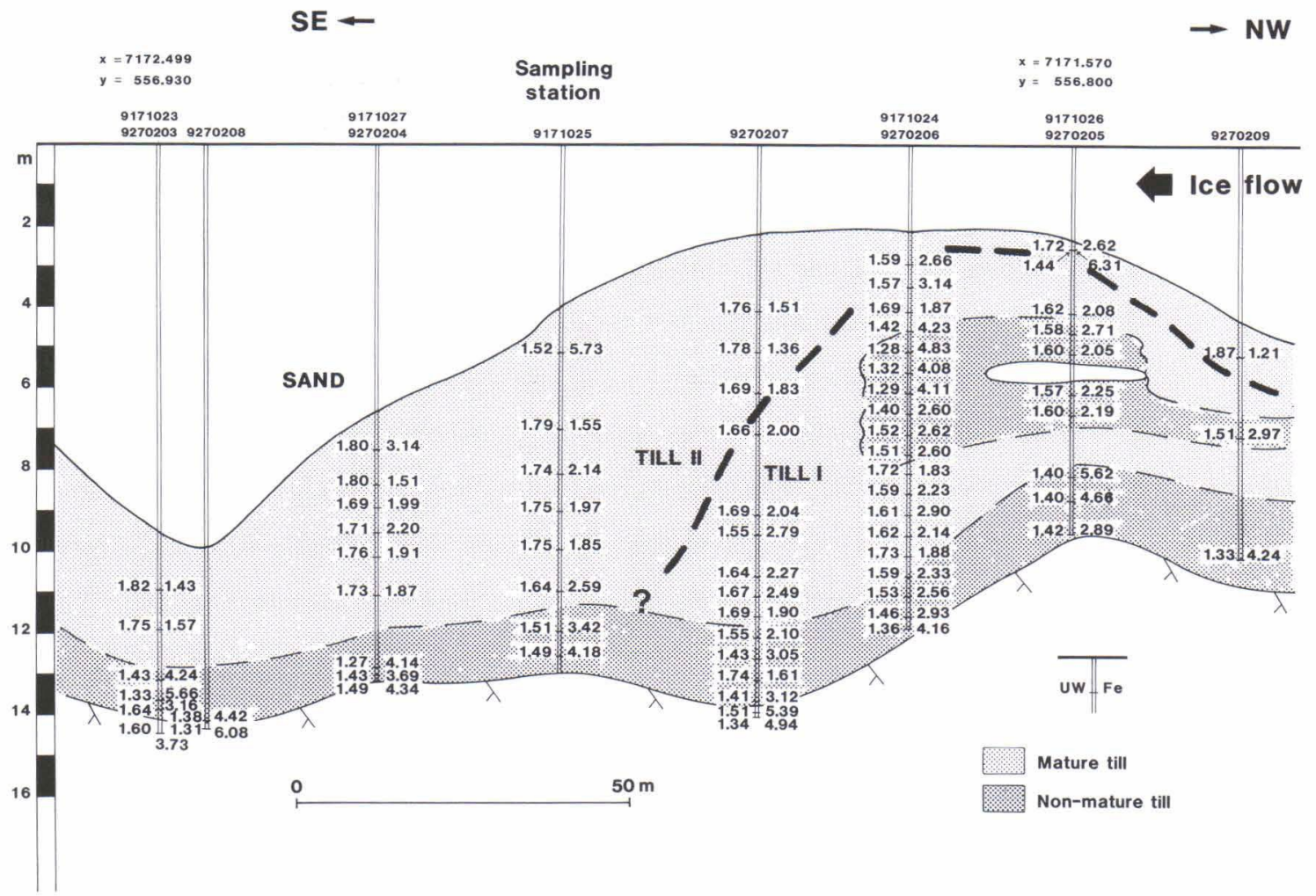

Fig. 11a. Cross-section of the sediments and bedrock topography based on percussion drill and GPR data. UW and Fe concentrations are also shown.

(more resistant minerals) relative to chlorite and mica (less resistant minerals). The mineralogical trend occurs in the first stage of the maturing progress since phyllosilicates are not only the least resistant mineral components; they are also the most susceptible to outwashing.

The validity of the hypothesis and observations can be tested by microscopic examination of till fabrics. Samples with high UW and maturity often have thick quartz-feldspar seams and low multielement concentrations. Thin phyllosilicate laminae between thick quartz-feldspar seams indicate efficient outwashing of clay-sized material. Outwashing also manifests itself in the deficiency of clay-sized material in the fine fraction with high UW (Fig. 9). Without the outwashing, increasing comminution would have increased the content of clay fraction. Low grade of the maturity is reflected in the massive fabric, or thick laminae/lenses with phyllosilicates, and in the inverse variable relationships.

According to Haldorsen (1983), the abundance of micas depends on the degree of both comminution and outwashing; but also on the types of till: basal lodgment till or melt-out till. The results of the present study suggest that outwashing is a more significant process for UW than comminution.

Maturity of till seems to be controlled by glaciodynamics. Material with high UW and a low multielement concentration occurs in the upper part of till bed II on the lee-side of elevations (sampling stations 9171023 and 9171027, Fig. 11a). Haldorsen (op. cit.) too, found that lee-side 


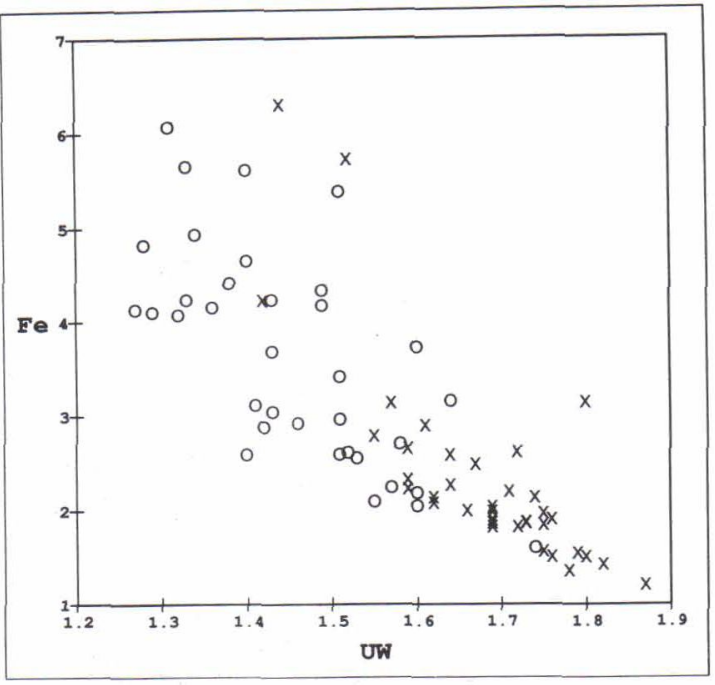

Fig. 11b. Bivariate plot of UW and Fe concentrations in Fig. 11a. $\mathrm{O}=$ the samples with low grade of maturity in Fig 11a, $\mathrm{X}=$ the samples with high grade of maturity in Fig 11a.

till is highly mature.

The sampling station data revealed that the multielement concentration level and the abundance of phyllosilicates generally increase towards the deepest part of the till beds, with a concomitant decrease in UW (Fig. 11a) (cf. Kauranne 1979). Occasionally, however, the lower till bed is more mature than the upper one, as shown by the reduction in the multielement concentration level towards the base of the till bed with the increase in UW (Fig. 12). The mineralogical composition varies as stated above. As regards with till stratigraphy in Fig. 12, it apparently represents till units Saalian and Weichselian in age (Nenonen et al. 1990). There is an analogy between tills in Pyhäsalmi, where the lower till contains less clay-sized fraction than the upper one (Hirvas et al. 1988, Nenonen 1985).

The dominant role of glacial processes explaining the variation in geochemical and mineralogical composition of till has emphasized earlier. Closer consideration, however, reveals a spatial dependence of the variation, since compositional scatter of till is greatest in the vicinity of bedrock whereas scatter decreases towards upper horizons (Fig. 11a,b). Briefly, the composition of bedrock affect most to the composition of till in the deepest part of till bed. The result is self evident in a way, but it helps to understand geological basis of variation and restrictions for the interpretation of geochemical data (cf. Salminen \& Hartikainen 1985). Emphasizing the bedrock factor in the geochemical till data, the sampling should be performed in the vicinity of the bedrock, where till is least mature (cf. Hirvas 1991 p. 39). In some cases it cannot be performed (see Fig. 12). Samples from the upper parts of till bed represent the population with high UW and the contribution of glacial processes in the total variation is emphasized.

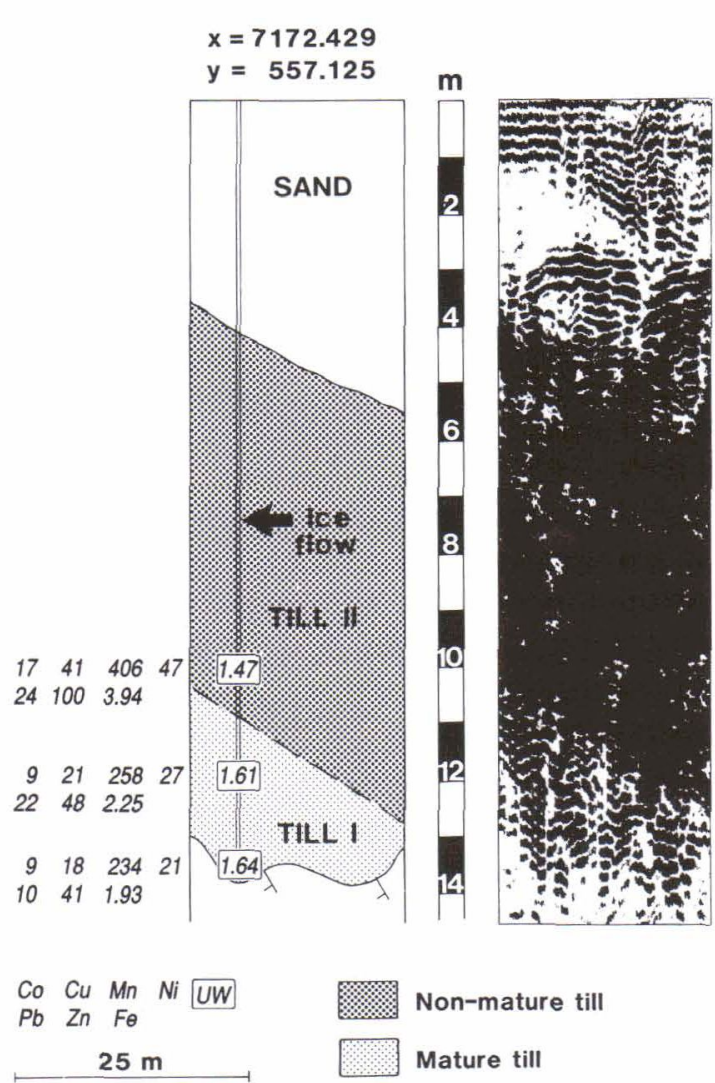

Fig. 12. Cross-section of the sediments indicating two till beds differing in physical and geochemical characteristics. The right-hand column is produced by GPR. 


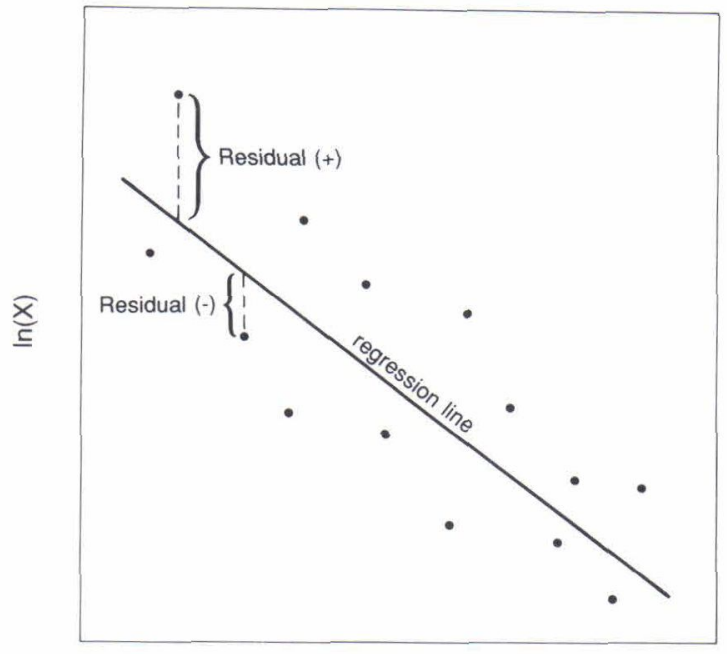

$\ln (\mathrm{UW})$

Fig. 13. A regression model of the element $\mathrm{X}$ and UW enables the bedrock and glacial information to be extracted from the till data. The residuals of the model depend on the bedrock geology, whereas the absolute values depend on both bedrock and glacial factors.

The quantitative aspect of glacial and bedrock factors has been discussed in earlier studies on till geochemistry (Koistinen \& Gaàl 1988, Lestinen et al. 1991). In the factor analysis of both the above studies, the first multielement factor explains $41 \%$ of the total variation, suggesting bedrock and/or glacial causality. The combined percentage of total variation for the second, third and fourth factors is generally less than 30 .

Mineralogical study of the fine fraction in Kiuruvesi-Pihtipudas area showed, that major multielement variation is linked to the maturity of till (Räisänen et al. 1992). On the other hand Mäkinen (1991) established on the statistical basis that the absolute concentration levels are related to glacial geology but the proportional concentration levels to bedrock. This indicates the existence of glacial and bedrock factors in the till data, and the dominant percentage of the glacial factor in the total variation (the first factor in Koistinen \& Gaàl 1988).

The scale of inspection applied in this study suggest an open system, but on an areal scale the situation is different. Even so, the same process seems to have occurred in both cases (Mäkinen 1991, Räisänen et al. 1992). It is therefore reasonable to suppose that, on an areal scale, glacial and bedrock factors can be distinguished with UW, reflecting the grade of maturity. The percentage of clay-sized material in the fine fraction also indicates the degree of maturity, but not as well as does UW (Fig. 10). As a whole, the residuals in the UW regression model should refer to relative concentrations, reflecting the composition of the bedrock (Fig. 13).

The dependence of UW on bedrock introduces some uncertainty into UW modelling. However, examination of geochemical parameters would give auxiliary information that can be used to extract the bedrock factor. For UW modelling it is important to know whether the fine fraction originates from felsic or mafic rocks.

The confidence of the regression model, which is highest for $\mathrm{Co}, \mathrm{Fe}, \mathrm{Mn}$ and $\mathrm{Ni}$ and lowest for $\mathrm{Cu}, \mathrm{Pb}$ and $\mathrm{Zn}$ (Figs. $3 \mathrm{a}-3 \mathrm{~g}$ ), can also be considered in statistical and geological terms. With decreasing UW, heteroscedasticity reduces the confidence of the model but then the till composition corresponds best to the bedrock composition. On the other hand, with increasing UW, the model and data are in good agreement but in this case the composition of till was modified in a progress of the maturity.

Application of the method provides fresh insight into the computing of till data. »Outwashing» the glacial information from the till data emphasizes the information inherited from the bedrock. It also enables the quality of the information to be evaluated, since maturity of till samples is indicated by UW. Consequently, the original till data should be considered as relative, but after UW reduction, the computing can be performed in Euclidean space.

Acknowledgements. I express my gratitude to Prof. S. Haldorsen and Prof. R. Salminen for useful comments on the manuscript. I thank Mrs. M. Nikkarinen, Mrs. M-L. Räisänen, Mr. P. Lestinen, Mr. K. Nenonen and Dr. P. Nieminen 
for numerous stimulating discussions. Laboratory equipments in the Geological Survey of Finland was used in conduct of Mr. H. Idman, Dr. P. Kallio and L. Westerberg. The language was checked by Mrs. G. Häkli.

\section{References}

Björklund, A., Kontio, M.\& Nikkarinen, M., 1976. Vihanti: The geochemical response of bedrock and ore in the overlying till. J. Geochem. Exploration, 5 (3), 370-373.

Dilabio, R.N.W., 1990. Glacial dispersal trains. In Kujansuu, R. \& Saarnisto, M. (Eds.) Glacial indicator tracing. 109-122. Balkema, Rotterdam.

Dreimanis, A. \& Vagners, U., 1971. Bimodal distribution of rock and mineral fragments in basal till. In Goldhwait, R.P. (Ed.) Till/A symposium, p. 27-37. Ohio State Univ. Press.

Gustavsson, N. \& Kontio, M., 1990. Statistical classification of regional geochemical samples using local characteristic models and data of the Geochemical Atlas of Finland and from the Nordkalott project. In Gaàl, G. \& Merriam, D. (Eds.) Computer applications in resource estimation, prediction and assessment for metals and petroleum. Computers and Geology, vol. 7, 1990, 23-41.

Haldorsen, S., 1983. Mineralogy and geochemistry of basal till and their relationship to till-forming processes. Norsk Geologisk. Tidsskrift 63, 15-25.

Hirvas, H., 1991. Pleistocene stratigraphy of Finnish Lapland. Geol. Surv. Finland Bull. 354, 123 p.

Hirvas, H., Kujansuu, R. \& Nenonen, K., 1988. Glacigenic deposits as indicators of glacial movements and their use for indicator tracing. In Goldhwaith, R.P. \& Matsch, C.H. (Eds.) Genetic classification of glacigenic deposits. Balkema, Rotterdam, 173-182.

Kauranne, L-M., 1979. Vihannin karttalehtialueen geokemiallisen kartoituksen tulokset. Summary: The results of the geochemical survey in the Vihanti map-sheet area. Geol. Surv. Finland. Explanatory notes to geochemical maps, Sheet 2434. 55 p.

Koistinen, E. \& Gaàl G., 1988. Integration of geochemical data. In Gaàl G. (Ed.) Exploration target selection by integration of geodata using statistical and image processing techniques: an example from Central Finland. Part I (Text). Geological Survey of Finland, Report of Investigation 80, 86-94.

Lestinen, P., Kontas, E., Niskavaara, H. \& Virtasalo, J., 1991. Till geochemistry of gold, arsenic and antimony in the Seinäjoki district, western Finland. J. Geochem. Exploration, 39, 343-361.

Lintinen, $P$., 1989. Onko moreenin savipitoisuudella vaikutusta hivenmetallipitoisuuksiin? Summary: The effect of clay content on trace metal contens in till. Geologi $41(9-10)$, $179-183$.

Mäkinen, J., 1991. Similarity analysis using rank in till geochemistry. Bulletin of the Geological Society of Finland. 63 (1), 49-57.

Nenonen, K., 1985. Till stratigraphy in the open pit section of the Pyhäsalmi mine, Pyhäjärvi, and a glacigenic $\mathrm{Zn}$ $\mathrm{Cu}-\mathrm{S}$ anomaly in the Pyhäsalmi ore body. In Saarnisto, M. (Ed.) INQUA till symposium. Finland 20-29 August 1985. Geological Survey of Finland, Department of Quaternary geology. Excursion guide. 75-89.

Nenonen, K., Eriksson, B. \& Grönlund, T., 1990. The till stratigraphy of Ostrobothnia, western Finland, with reference to new Eemian interglacial sites. Striae, 34, in press.

Nieminen, $P$. , 1985. Moreenin hienoaineksen laatu ja sen vaikutus routimisherkkyyteen. Tampere University of Technology publications 34. Summary in English. 81 p.

Nikkarinen, M.E., Mäkinen, J.E., \& Salminen, R.K., 1991. Statistical interpretation of the regional geochemical mapping data based on the heavy fraction of till in southern Finland. Geological Survey of Finland, Special Paper 12, $181-186$.

Norusis, M.J., 1990. SPSS/PC + statistics 4.0 for the IBM $\mathrm{PC} / \mathrm{XT} / \mathrm{AT}$ and PS/2. SPSS inc.

Nykänen, O., 1959. Geological map of Finland, sheets 24412443, $1: 100$ 000. Geological Survey of Finland.

Peuraniemi, V., 1982. Geochemistry of till and mode of occurrence of metals in some moraine types in Finland. Geological Survey of Finland, Bulletin 322, 75 p.

Perttunen, M., 1977. The lithologic relation between till and bedrock in the region of Hämeenlinna, southern Finland. Geological Survey of Finland, Bulletin 291, 68 p.

Räisänen, M-L., Tenhola, M. \& Mäkinen, J., 1992. Relationship between mineralogy and the physico-chemical properties of till in central Finland. Bulletin of the Geological Society of Finland, 64, 35-58.

Salminen, R., 1980. On the geochemistry of copper in the Quaternary deposits in the Kiihtelysvaara area, North Karelia, Finland. Geological Survey of Finland Bulletin 309, 48 p.

Salminen, R. \& Hartikainen, A., 1985. Glacial transport of till and its influence on interpretation of geochemical results in North Karelia, Finland. Geological Survey of Finland, Bulletin 335, 48 p.

Schiffman, S., Reynolds, M. \& Young, F., 1981. Introduction to Multidimensional Scaling. Academic Press. Inc., 
Orlando, Florida. 402 p.

Soveri, U. \& Kauranne, L.K., 1972. Rakennusgeologia I. Teknillisen korkeakoulun ylioppilaskunta. Otaniemi. 194 p.

Stewart, R.A. \& Broster, B.E., 1990. Compositional variability of till in marginal areas of continental glaciers. In
Kujansuu, R. and Saarnisto, M. (Eds.) Glacial indicator tracing. 123-149. Balkema, Rotterdam.

Received January 2, 1992

Revision accepted May 15, 1992 